\title{
INTRA-INDUSTRY TRADE BETWEEN INDIA AND INDONESIA
}

\author{
C.T. Vidya ${ }^{1}$ and K.P. Prabheesh ${ }^{2}$ \\ ${ }^{1}$ Centre for Economic and Social Studies, Hyderabad, India. Email: ctvidya@gmail.com \\ ${ }^{2}$ Department of Liberal Arts, Indian Institute of Technology, Hyderabad, India. \\ Email: prabheeshkp@gmail.com
}

\begin{abstract}
This paper analyzes the determinants of India's Intra-Industry Trade (IIT) with its trading partner, Indonesia, from 1995 to 2017. We estimate India's IIT with Indonesia using bilateral commodity trade data at the two-digit Broad Economic Categories classification code level. Our estimates of IIT demonstrate that India's trade with Indonesia is indeed intra-industry in nature. However, no remarkable improvements in the intensity of IIT is found. We also examine the determinants of IIT by estimating a standard IIT equation using an autoregressive distributed lag model. Our empirical findings reveal that trade imbalances, disparity in the demand structure, and the human capital endowments among the countries reduce bilateral IIT and that foreign direct investment and trade openness play an important role in enhancing it. This study therefore suggests relevant policy interventions to facilitate fair trade by reducing barriers.
\end{abstract}

Keywords: Intra-industry trade; Grubel-Lloyd index; Autoregressive distributed lag model. JEL Classifications: F12; F14.

Article history:

Received : July 10, 2018

Revised : September 28, 2018

Accepted : December 17, 2018

Available online : January 31, 2019

https://doi.org/10.21098/bemp.v0i0.978 


\section{INTRODUCTION}

Asian countries' participation in global trade has increased substantially during the last two decades. Globalization has altered Asia's trade patterns and paved the way for the internationalization of production networks linking across borders. The rapid growth of trade is closely related to specialization, where consumers seek "product variety" or indulge in "love for variety." Trade specialization through export-oriented industrialization leads to international fragmentation of the production process, which has contributed to the increasing importance of Intra-Industry Trade (IIT) in Asian countries (Haddad, 2007). Fragmented trade links the production process located in different countries, thus reaping economies of scale and efficiency. Fragmented trade also enhances the gains from trade through comparative advantages in the production process, as noted in new trade theories such as economies of scale and product differentiation (Krugman, 1981; Falvey and Kierzkowski, 1986).

Hence, IIT is a phenomenon that arises when a country simultaneously exports and imports goods produced by the same industry (Balassa, 1986). IIT is presumed to occur between developed countries with similar factor endowments. However, it is argued that, within Asian economies, IIT also plays a vital role in the production process, trade, and growth (Sawyer et al., 2010). Asian economies are the major players in international fragmentation, as production of goods fragmented into several stages, with each stage produced in the most cost-effective location or country. Therefore, goods cross borders several times before being transformed into final products, further increasing trade interconnectedness. Emerging countries in Asia tend to be downstream in the supply chain, with relatively large shares of imported content in their exports (International Monetary Fund, 2011).

The literature in the context of IIT is mostly focused within major three strands: i) measuring IIT (Grubel and Lloyd, 1975: Brulhart, 1994), ii) theoretical developments within IIT (Linder, 1961; Falvey, 1981; Helpman and Krugman, 1985), and iii) empirical studies examining the determinants of IIT (Bergstrand, 1983; Balassa, 1986; Andresen, 2003; Zhang and Li, 2006; Clark and Denise, 1999). In the third strand, many empirical studies have analyzed the determinants of IIT among Asian economies (Menon, 1996; Sohn and Zhang, 2005; Thorpe and Zhang, 2005; Cortinhas, 2007; Sawyer et al., 2010). However, the bilateral analysis of Asian countries such as India and Indonesia is a less explored area of research. A bilateral trade analysis is more focused than a multilateral one, since it is between two countries. Moreover, a bilateral analysis explores the comparative advantages between the two countries, the scope of economies of scale, and possible areas of specialization that can help in framing policies to reduce trade barriers and in developing regional trade agreements. Hence, the present study analyzes the trade pattern of India with Indonesia by exploring the determinants of IIT between the two countries.

India, one of the emerging economies in the world, has extensively involved in international trade and developed strong multilateral and bilateral trade relations with major countries. Economic reforms initiated in 1991 led to significant changes in the country's trade patterns and direction. In 1991, India's commodity trade was primarily dominated by Organization for Economic Cooperation and Development (OECD) countries, with an export share of $56.6 \%$ and 
an import share of $57.2 \%$, but, by 2017-2018, these shares had declined to $39.4 \%$ and $27.2 \%$, respectively. During the same period, the country's export share with Asia increased from $14.4 \%$ to $32 \%$ and its share of imports increased from $14.4 \%$ to $35.6 \%$ (OECD, 2018). These shifts in the destination of trade indicate India's growing interconnectedness with Asian economies.

Among Asian economies, India's trade with Indonesia also increased substantially during this period. Indonesia has emerged as India's largest trading partner within Asia.

\section{Figure 1. Trends in India's Trade with Indonesia (in USD Million)} The figure presents the trends in India's trade (in USD million) with Indonesia. The data come from the Direction of
Trade Statistics, Handbook of Economics and Statistics, RBI.

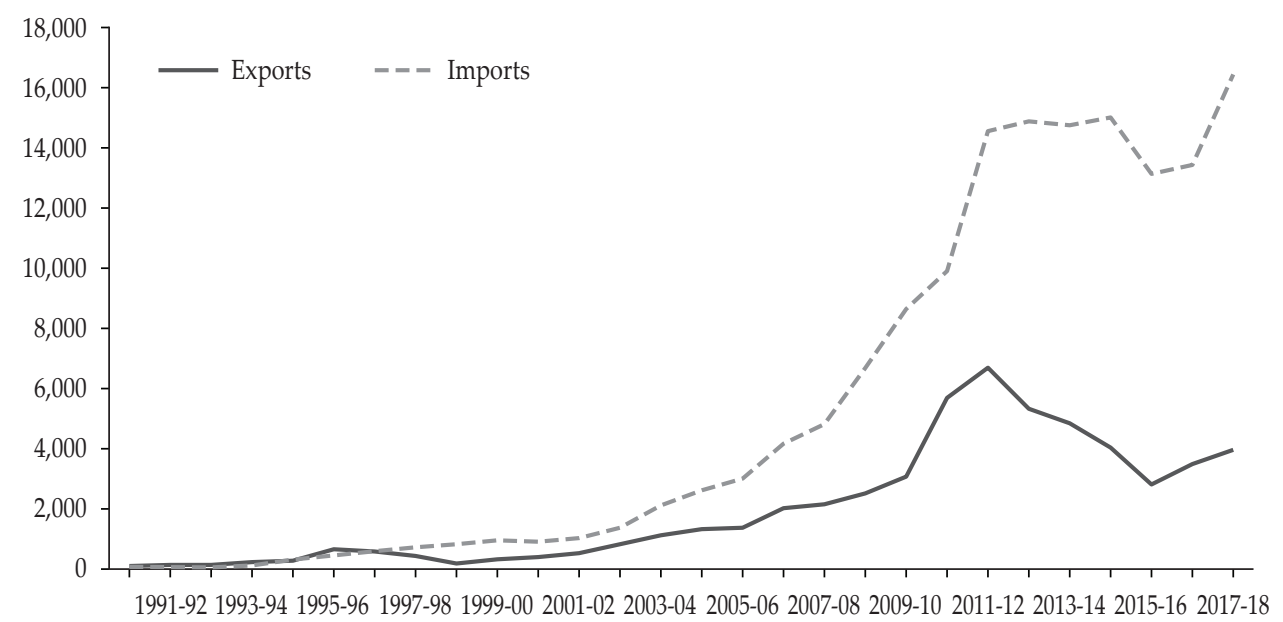

Figure 1 shows the increasing trend of India's exports and imports with Indonesia between 1990-1991 and 2013-2014. It is important to highlight that India's exports increased from USD 109 million to USD 3,964 million between 1990-1991 and 2017-2018. At the same time, India's imports from Indonesia have displayed greater dynamism, rising from USD 81 million to USD 16,438 million during the same period. Therefore, Indonesia is an attractive import source for India, compared to India as an export destination for Indonesia. Subsequently, India's trade balance with Indonesia dropped from a surplus of USD 28 million in 1990-1991 to a trade deficit of USD 12,475 million in 2017-2018. 


\section{Figure 2. India's Top Import Sources}

The figure presents India's top ten import countries (in USD million) in the year 2017. The data come from the Direction of Trade Statistics (DOTS), International Monetary Fund (IMF).

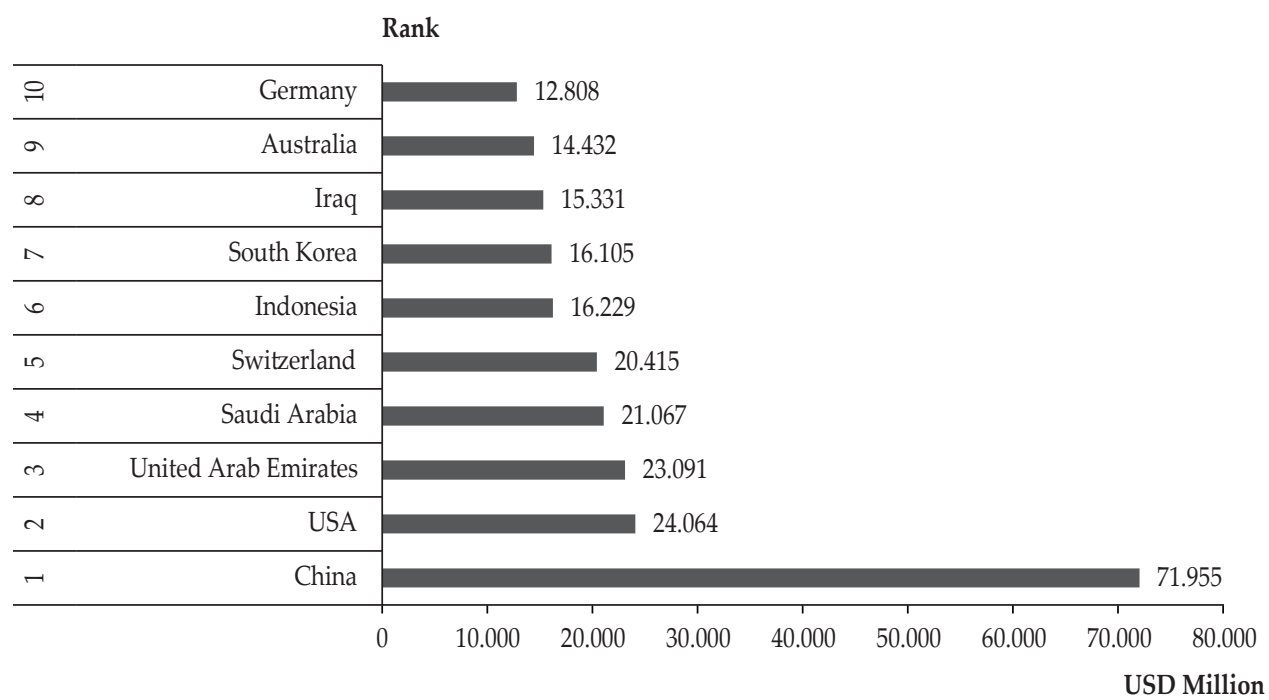

Figure 2 shows Indonesia as the sixth largest import source for India. India's import basket mainly consists of coal and crude palm oil, minerals, rubber, pulp and paper, and hydrocarbons reserves, whereas India exports refined petroleum products, maize, commercial vehicles, telecommunication equipment, oil seeds, animal feed, cotton, steel products, and plastics to Indonesia (Ministry of Commerce, India 2016). Given the large trade imbalance between India and Indonesia, it is essential to analyze the inherent pattern of trade between the two. This bilateral analysis will help understand the potential of trade specialization and trade reciprocity and further devise suitable policies to promote bilateral ties between the two countries.

We hypothesize that countries with similar per capita incomes will have similar demand structures and export similar products, with greater IIT, in line with Linder (1961). Accordingly, consumers' tastes are conditioned by their income levels and create product demand and this demand structure generates a production response. Hence, countries with similar per capita incomes will have similar demand structures and will export similar goods. On the other hand, greater differences in per capita income lead to greater disparity in the demand structures of the countries, which will be reflected in lower relative levels of IIT (Loertscher and Wolter, 1980; Greenaway et al., 1994). ${ }^{3}$ Second, we

\footnotetext{
3 As per theory, a high-income, capital-abundant developed country specializes in exporting highquality products, whereas developing countries focus on producing and exporting low-quality products, since their low-income consumers prefer these cheaper products. It is love for variety that consequently leads to vertical specialization in IIT.
} 
also presume that disparities in human capital endowments will reduce IIT. As Balassa (1986) shows, differences in human capital endowments largely explain inter-country differences in the structure of exports. In other words, countries with similar factor endowments are likely to focus on the trade of varieties of goods of similar quality, whereas countries with different factor endowments tend to specialize in the trade of varieties of goods of different quality, which is a more vertical type of specialization (Falvey, 1981). Finally, greater trade openness and Foreign Direct Investment (FDI) will intensify IIT specialization. According to the literature (Baldwin, 1979; Caves, 1981; Markusen, 1983), opening up trade promotes simultaneous exports and imports in the same industry and thus more IIT. Similarly, the penetration of foreign firms through FDI will promote product differentiation in the industry, which is an integral part of IIT.

The approach of this study is to estimate a standard IIT equation by incorporating the above factors as independent variables, using annual data from 1995-2017 and an Auto-Regressive Distributed Lagged (ARDL) approach to cointegration. Our findings suggest that bilateral IIT between India and Indonesia does not grow over the sample period. The disparity in demand structure and human capital endowments between countries significantly reduces IIT. Finally, FDI and trade openness have a significant positive effect on IIT.

Hardly any studies have analyzed the patterns of trade between India and Indonesia using the IIT concept and exploring specialization. ${ }^{4}$ Our results mostly indicate that policies that help open up trade and invite FDI will help a country specialize in trade and hence gain from it. Our results are in line with those of Markusen and Venables (1998, 2000) Leamer (1988), and Harrigan (1994), for example.

The remainder of this paper is organized as follows. Section II presents the theoretical background and measurement of IIT. Section III describes the empirical model. Section IV discusses the data and econometric methodology. Section V presents the empirical findings and Section VI concludes the paper.

\section{THEORETICAL BACKGROUND AND MEASUREMENT OF IIT}

Traditional Hecksher-Ohlin-Samuelson (HOS) theory is based on the idea that each industry produces a single homogeneous product and each country will export that commodity in which it has a comparative advantage in the production or relative factor abundance. Similarly, a country will import those commodities in which it has a comparative disadvantage. This reflects the case for inter-industry trade, in that there will be no reciprocal trade in products to the same industry. However, empirical studies in the 1960s and 1970s highlight that a considerable proportion of world trade can be defined as IIT, wherein a country simultaneously imports and exports (differentiated) products that are close substitutes for each other within the same industry. Traditional HOS theory fails to explain IIT, stimulating a large number of new theoretical models that try to explain this new phenomenon.

4 Related studies in this context largely focus on the IIT patterns of Asian economies, including those of India and Indonesia (Wakasugi, 2007). 
The development of the IIT concept is based on new trade theories. New trade theories consider monopolistic competition with increasing returns to scale, as opposed to the perfect competition and constant returns to scale envisaged by the HOS model. One of the first extensions of HOS theory was developed by Linder (1961), who proposed demand similarity ${ }^{5}$ which contributes to trade in undifferentiated products. This important extension of HOS theory is well elaborated by Helpman and Krugman (1985). Similarly, Falvey (1981) and Falvey and Kierzkowski (1987) have developed an underlying theory behind IIT based on factor endowment envisaged in the HOS trade theory. The recent theory of IIT developed by Davis (1995) based on technological differences between countries is founded on traditional trade theory, which also emphasizes factor endowment as a determinant of comparative advantage among countries. Hence, factor endowment is considered an important factor in both IIT and comparative advantage theories.

Krugman (1981) has developed theory on trade in the presence of monopolistic competition and shows that economies of scale and product differentiation are the two main factors that differentiate modern trade theory from the HOS trade model and they are important in determining the level of IIT between countries. Similarly, Leamer (1988) and Harrigan $(1994,1996)$ demonstrate that opening up markets leads to larger trade volumes and, hence, increases the likelihood of IIT between certain countries. Furthermore, Markusen and Venables $(1998,2000)$ find FDI to be an important factor that contributes to product differentiation and increases in the volume of IIT. As observable from the above-mentioned studies, the underlying theory behind IIT has evolved over time as researchers try to capture the contemporary trade relationships between various countries. Factors identified as the key determinants of IIT are demand similarities, economies of scale, product differentiation, market openness, and FDI (Loerstcher and Wolter, 1980; Fainštein and Netšunajev, 2011).

In the Indian context, studies have primarily focused on examining the pattern and determinants of IIT from a multilateral trade perspective. Veeramani (2002) examines India's IIT with a group of developed and developing countries and finds that its IIT with developed countries is more intense than that with developing countries. The study also finds that the key determinants are per capita income differences, technology gaps, and differences in human capital endowment. Veeramani (2007) finds that exports promoting FDI have a positive impact on India's IIT. Similarly, Burange and Chaddha (2008) find that IIT in industrial goods increased from 1987-1988 to 2005-2006 and is greater with the regions of Asia and Europe. Similarly, analyzing the level of IIT in India's processed food sector, Varma (2015) finds that differences in factor endowments in the agriculture sector lower the level of IIT. Similarly, Aggarwal and Chakraborty (2017) find that factors such as technology, income differences, and trade facilitation measures have significantly determined India's IIT with its 25 major trading partners from 2001 to 2005 .

\footnotetext{
5 "The more similar the demand structure of the two countries the more intensive potentially is the trade between these two countries." (Linder, p.94, 1961)
} 
In this study, the extent of India's bilateral IIT with Indonesia is computed using the standard Grubel-Lloyd (1975) index, in the following weighted average form:

$$
I I T_{i j}=1-\frac{\left|X_{i j}-M_{i j}\right|}{\left(X_{i j}+M_{i j}\right)}
$$

where $X_{i j}$ and $M_{i j}$ are the home country's (i.e. India) exports of industry $i$ to partner country $j$ (i.e. Indonesia) and the home country's imports of industry $i$ from partner country $j$, respectively. Thus, the $I I T_{i j}$ index in equation (1) measures the share of $I I T$ in industry $i$ with country $j$. If all trade in industry $i$ is $I I T$, that is, $X_{i j}=M_{i j^{\prime}}$ then $I I T_{i j}=1$. Similarly, if all trade in industry $i$ is inter-industry, that is, either $X_{i j}=0$ or $M_{i j}=0$, then $I I T_{i j}=0$. Thus, the index of IIT takes on values from zero to one as the extent of IIT increases, that is, $0 \leq I I T_{i j} \leq 1$.

The IIT index in equation (1) can be modified to measure IIT in all products with country $j$ as a weighted measure of the $I I T_{i j}$ terms:

$$
\begin{aligned}
& I I T_{j}=\sum_{i=1}^{n} w_{i j}\left[1-\frac{\left|X_{i j}-M_{i j}\right|}{\left(X_{i j}+M_{i j}\right)}\right] \\
& \text { where } w_{i j}=\left[1-\frac{\left(X_{i j}+M_{i j}\right)}{\sum_{i=1}^{n}\left(X_{i j}+M_{i j}\right)}\right] \text { that is, IIT }=\left[\frac{\sum_{i=1}^{n}\left(X_{i j}+M_{i j}\right)-\sum_{i=1}^{n}\left|X_{i j}-M_{i j}\right|}{\sum_{i=1}^{n}\left(X_{i j}+M_{i j}\right)}\right]
\end{aligned}
$$

with $n$ the number of industries at a chosen level of aggregation.

To construct India's bilateral IIT index with Indonesia, we take India's exports and imports of commodities to and from Indonesia, by industry, for the period 1995 to 2017. Following the Broad Economic Categories (BEC) classification of the United Nations (UN), we use the two-digit classification codes of commodities. Accordingly, commodity trade is classified into 14 categories: primary and processed food and beverages (BEC codes 11 and 12, respectively), primary and processed industrial supplies (BEC codes 21 and 22), primary and processed fuels (BEC codes 31 and 32), capital goods (BEC codes 41 and 42), transport equipment components (BEC codes 51-53), and durable, semi-durable, and non-durable consumer products (BEC codes 61-63). The primary purpose of calculating IIT at the two-digit BEC code level is to reduce bias, since calculations of IIT based on higher levels of aggregation yield inflated estimates (Gullstrand, 2002) ${ }^{6}$.

\footnotetext{
6 The Grubel-Lloyd (GL) index is a weighted mean, since the share of some commodity groups can be higher than others within total exports and imports. A simple average of the IIT indices of disaggregated commodities would thus give misleading results.
} 
Figure 3. IIT Index (Bilateral IIT between India and Indonesia)

The figure presents the Grubel-Lloyd Intra-industry trade index of specialization between India and Indonesia. The value of GL index ranges from 0 to 1 and GL takes the value 0 if there is no IIT, and takes the value 1 when all trade is IIT. The data for calculation of index was taken from Direction of Trade Statistics, Handbook of Economics and Statistics, RBI.

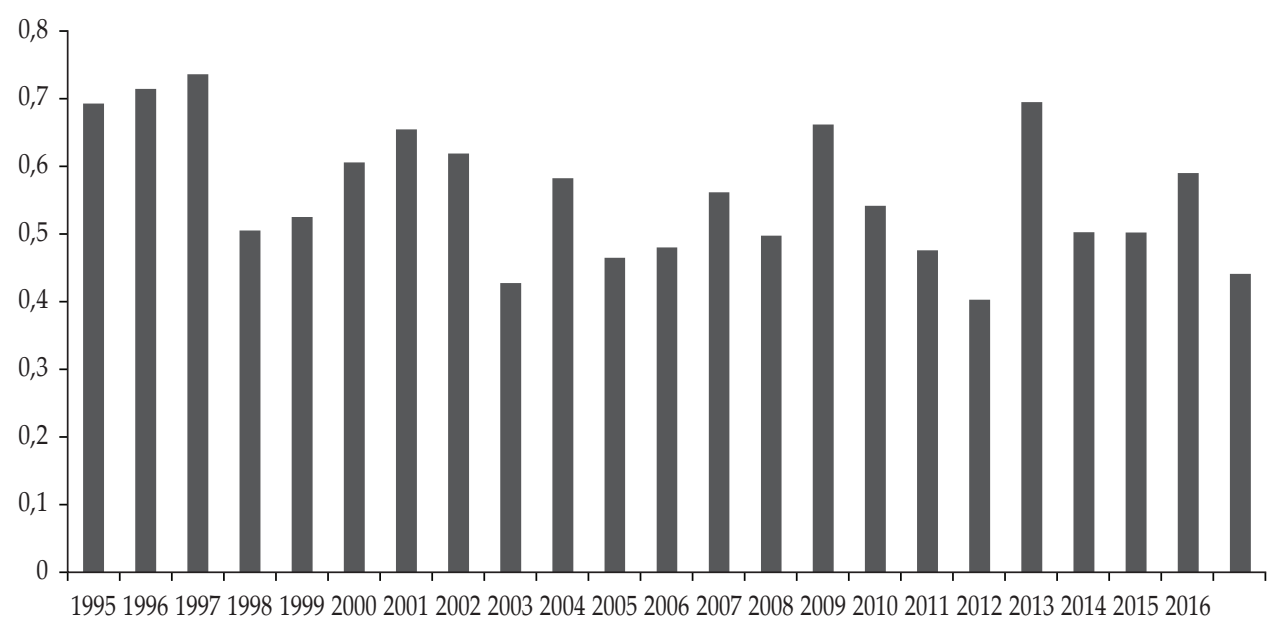

Table 1.

Commodity Wise Contributions to Aggregate IIT

The table shows the five-year average percentage contribution of each commodity category to the aggregate IIT. Here aggregate IIT is the sum of the weighted average of IIT of each commodity group.

\begin{tabular}{lccccc}
\hline Period & $\mathbf{1 9 9 6 - 2 0 0 0}$ & $\mathbf{2 0 0 1 - 0 5}$ & $\mathbf{2 0 0 6 - 1 0}$ & $\mathbf{2 0 1 1 - 1 5}$ & $\mathbf{2 0 1 6 - 1 7}$ \\
\hline Food and beverages (primary) & 9.6 & 8.9 & 7.6 & 5.5 & 5.5 \\
Food and beverages (processed) & 6.0 & 12.4 & 2.5 & 3.9 & 8.0 \\
Industrial supplies (primary) & 4.0 & 5.3 & 9.3 & 14.8 & 5.5 \\
Industrial supplies (processed) & 71.7 & 60.4 & 60.0 & 51.8 & 53.1 \\
Capital goods & 2.8 & 3.2 & 5.7 & 8.7 & 10.7 \\
Parts and accessories of capital goods & 2.3 & 4.4 & 4.0 & 5.2 & 4.0 \\
Fuels and lubricants (processed) & 1.1 & 0.3 & 6.3 & 1.7 & 2.0 \\
Fuels and lubricants (primary) & 1.1 & 0.3 & 6.3 & 1.7 & 2.0 \\
Others & 2.1 & 4.4 & 3.2 & 5.3 & 7.9 \\
\hline
\end{tabular}

Figure 3 depicts the calculated IIT index and shows that the values are above 0.5 in most years, indicating IIT between India and Indonesia. However, the trends indicate the IIT is not increasing, implying that the full potential of specialization is not being exploited. This result also highlights the limited reciprocity of the trade between the two countries. Further, Table 1 reports the commodity-wise contributions to total IIT. It shows that the processed industrial supply commodity group accounted for a larger share, more than 70\%, during 1996-2000, which 
subsequently declined to 53\% during 2016-2017. In the same period, the share of capital goods increased from $2.8 \%$ to $10.7 \%$, highlighting the inclination toward trade specialization in the sector. It is also interesting to note that the contribution of food and beverages (primary) declined from $9.6 \%$ to $5.5 \%$ and the share of food and beverages (processed) increased from $6 \%$ to $8 \%$ during the same period. These figures reveal that specialization takes place more with processed than with primary products. It is also important to note that, over the years, trade between India and Indonesia has moved away from primary products to more industrial processed commodities. This indicates a significant change in the trade patterns between the two countries in terms of composition, that is, a shift from labor-intensive to more capital-intensive products. Further, the increasing IIT in processed commodities indicates the scope of specialization in these commodities, where rising economies of scale and product differentiation have a significant influence. ${ }^{7}$

The above discussion highlights the following facts: 1) trade between India and Indonesia has been increasing over the years, 2) IIT between the two countries has not grown during 1995-2017, implying there is room for further specialization, and 3) IIT is exploited in commodity groups such as processed industries and capital goods. Given this scenario, it is crucial to understand the underlying factors that determine the level of IIT between the two countries to exploit the full potential of specialization and reap the gains from trade.

\section{EMPIRICAL MODEL OF BILATERAL IIT}

We specify the following bilateral IIT equation in log-linear form, in line with Balassa and Bauwens (1987):

$$
\begin{aligned}
\ln I I T_{i j t}= & \beta_{0}+\beta_{1} \ln R D P C I_{i j t}+\beta_{2} \ln T B_{i j t}+\beta_{3} \ln F D I_{i j t}+\beta_{4} \ln M S D_{i j t}+ \\
& \beta_{5} \ln H K E_{i j t}+\beta_{6} \ln \text { Open }_{i j t}+\varepsilon_{i j t}
\end{aligned}
$$

where $i$ stands for the home country, India; $j$ stands for its respective trading partner, Indonesia; $\beta_{1}, \beta_{2}, \beta_{3}, \beta_{4}, \beta_{5}$, and $\beta_{6}$, are the parameters to be estimated; $\beta_{0}$ is the intercept; $t$ denotes time; and $\varepsilon_{i j t}$ stands for the error term. All variables are expressed in logarithmic form. The variable IIT indicates the weighted GrubelLloyd index for India's trade with Indonesia. Similarly, RDPCI is the relative difference in per capita income between India and Indonesia, an indicator of demand structure and a proxy for inequality in economic development. In other words, the difference in per capita income measures the extent of variation in demand for differentiated products. IIT would tend to be more intense between countries with more similar levels of per capita income.

\footnotetext{
Increasing economies of scale have a long-run decreasing trend in average cost and, during that time, most countries concentrate their limited factors of production on smaller numbers of huge firms. This helps in the exploitation of all the advantages and is a common phenomenon in many industrial processes (Maric, 2011).
} 
The variable $T B$ is the trade balance between India and Indonesia, where the higher the trade imbalance, the lower the IIT $\left(\beta_{1}<0\right)$. In other words, lowering trade barriers and opening up a country to trade promotes simultaneous exports and imports in the same industry and reduces trade imbalances and hence increases IIT. Apart from that, since the IIT indexes are generally biased toward trade imbalance, the trade balance is usually included in models of IIT determination to correct for this (Xing, 2007).

The variable FDI stands for inflows of FDI from partner countries to the home country. Higher FDI from partner countries is expected to increase the home country IIT, since it leads to product differentiation and higher economies of scale and hence $\beta_{3}>0 .{ }^{8}$ In other words, FDI promotes IIT, particularly when foreign companies are set up to take advantage of the host country's factor endowments and their production is subsequently exported back to it.

The variable MSD stands for the market size differential between the home country and the partner country. The greater the Market Size Differential (MSD), the lower the level of IIT between countries $\left(\beta_{4}<0\right)$. "As economies become more similar in terms of their market size, the potential for overlapping demand for differentiated products is enhanced" (Sawyer et al., p.487,2010). The variable HKE captures the difference in the level of human capital endowment between the home and partner countries. Large differences in factor endowments can reduce IIT and increase inter-industry trade rather than IIT (Helpman and Krugman, 1985). Finally, Open indicates the level of trade openness in India and the greater the openness, the higher the levels of IIT.

\section{DATA AND METHODOLOGY}

The study uses annual data from 1995 to 2017. Disaggregated bilateral export and import data are obtained from the UN's Comtrade Database and the rest of the data is from the World Bank and UNESCO websites ${ }^{9}$. The beginning period analysis is attributed to the availability of disaggregated bilateral trade data on India and Indonesia under the BEC classification. The details of the measurement of the variables in Equation (3) are given in the Appendix.

Equation (3) is estimated using the ARDL cointegration procedure developed by Pesaran and Shin (1999) and Pesaran et.al (2001). This test can be performed irrespective of whether variables in the model are purely $\mathrm{I}(0)$, purely $\mathrm{I}(1)$, or mutually cointegrated. The ARDL cointegration procedure involves two steps. The first step is to examine the existence of a long-run relationship between the variables in the model. If cointegration exists, the second step is to estimate the

8 There are two different schools of thought on the relationship between FDI and IIT. One school argues that goods produced in multinational economies are differentiated and involved firms engage in either horizontally or vertically trading the differentiated goods to meet different incomes and tastes. The second school of thought states that most IIT is intra-firm trade between multinational economies and follows a fragmented production process in different countries (Chen, 2000).

9 https://data.worldbank.org and http://data.uis.unesco.org 
long- and short-run coefficients using associated ARDL and error correction models. The error correction model of the ARDL model pertaining to the variable is

$$
\begin{aligned}
\Delta \ln I I T_{t}= & \alpha_{0}+\lambda_{1} \ln I I T_{t-1}+\lambda_{2} \ln R D P C I_{t-1}+\lambda_{3} \ln T B_{t-1}+\lambda_{4} \ln F D I_{t-1}+ \\
& \lambda_{5} \ln M S D_{t-1}+\lambda_{6} \ln H K_{t-1}+\lambda_{7} \ln \text { Open }_{t-1}+\sum_{i=1}^{p} \beta_{i} \Delta \ln I I T_{t-i}+ \\
& \sum_{i=1}^{p} \delta_{i} \Delta \ln R D P C I_{t-i}^{*}+\sum_{i=1}^{p} \phi_{i} \Delta \ln T B_{t-i}^{*}+\sum_{i=1}^{p} \gamma_{i} \Delta \ln F D I_{t-i}+ \\
& \sum_{i=1}^{p} \theta_{i} \Delta \ln M S D I_{t-i}+\sum_{i=1}^{p} \omega_{i} \Delta \ln H K_{t-i}+\sum_{i=1}^{p} \omega_{i} \Delta \ln \text { Open }+u_{t}
\end{aligned}
$$

where the first part of the right-hand side with parameter $\lambda$ represents the longrun relationship and the second part, with $\beta, \delta, \gamma, \phi, \theta$, and $\omega$, represent the shortrun dynamics of the model.

To examine the existence of a long-run relationship between IIT and its determinants, an F-test procedure is followed for the joint significance of the coefficients of the lagged levels of the variables, that is, $H_{0}: \lambda_{1}=\lambda_{2}=\lambda_{3}=\lambda_{4}=\lambda_{5}=\lambda_{6}$ $=\lambda_{7}=0$ against $H_{1}: \lambda_{1} \neq \lambda_{2} \neq \lambda_{3} \neq \lambda_{4} \neq \lambda_{5} \neq \lambda_{6} \neq \lambda_{7} \neq 0$. If the null hypothesis is rejected, this indicates the existence of a long-run relationship or cointegration. Pesaran et al. (2001) propose lower and upper critical values for the F-statistic, assuming all variables are $\mathrm{I}(0)$ for the lower bound and all variables are I(1) for the upper bound. If the computed $F$-statistic exceeds the upper critical value, then the null of no cointegration can be rejected, irrespective of the order of integration of the variables. Conversely, if the test statistic falls below the lower critical bound, then the null of no cointegration cannot be rejected.

As a third alternative, if the test statistic falls between the lower and upper critical values, then the result is inconclusive. In the present case, the critical values proposed by Narayan (2005) for a small sample size are used. If cointegration is established, then the long-run coefficients can be estimated by the ARDL model using ordinary least squares. Since the ARDL model assumes no serial correlation in errors, an appropriate lag level $(m)$ should be chosen. We estimate a total of $(m+1)^{k+1}$ different ARDL models, where $k$ is the number of variables, and choose a model based on information criteria such as Akaike's information criterion or Schwarz's Bayesian information criterion. The short-run dynamics are then estimated through the error correction model.

\section{EMPIRICAL RESULTS}

First, we use the augmented Dickey-Fuller and Phillips-Perron tests to check the stationarity of the variables. The results are reported in Table 2 . They indicate that all variables are found to be integrated with order one, except the difference in human capital endowments (HKE). This evidence of the mixed order of integration of the variables, that is, $\mathrm{I}(0)$ and $\mathrm{I}(1)$, enables us to employ the ARDL approach to cointegration for estimation. 


\section{Table 2.}

\section{Results of Unit Root Test}

The table shows the unit root test of the variables based on Augmented Dickey-Fuller (ADF), Phillips-Perron (PP). The null and the alternative hypotheses are series is non-stationary (contains unit root) and series is stationary (no-unit root), respectively. The test statistic of ADF and PP are compared with critical values tabulated by MacKinnon (1994) and MacKinnon (1996), respectively. Lags are selected automatically using Schwarz Information criterion (SBC). Where, ${ }^{*}$ denotes rejection of unit root at $1 \%$. The sample period used is from 1995 to 2017. Where, IIT, RDPCI, $T B$ and FDI denote Grubel-Lloyd Intra-industry trade index, relative difference in per-capita income, trade balance, foreign direct investment, respectively. Similarly, MSD, HKE and Open denote market size differential, human capital differential and trade openness, respectively. $\ln$ is the natural logarithm.

\begin{tabular}{lcccc}
\hline \multirow{2}{*}{ Variables } & \multicolumn{2}{c}{ ADF Test Statistic } & \multicolumn{2}{c}{ PP Test Statistic } \\
\cline { 2 - 5 } & Levels & First Difference & Levels & First Difference \\
\hline $\ln I I T$ & -1.481 & $-4.801^{*}$ & -1.44 & $-6.02^{*}$ \\
$\ln R D P C I$ & 0.055 & $-4.39^{*}$ & -0.042 & $-4.44^{*}$ \\
$\ln \mathrm{TB}$ & 0.68 & $-3.87^{*}$ & 0.72 & $-3.81^{*}$ \\
$\ln \mathrm{FDI}$ & 1.55 & $-3.22^{*}$ & 1.55 & $-3.24^{*}$ \\
$\ln \mathrm{MSD}$ & 2.55 & $-3.77^{*}$ & 2.61 & $-2.68^{*}$ \\
$\ln H K E$ & $-3.35^{*}$ & $-6.033^{*}$ & -4.21 & $-7.52^{*}$ \\
$\ln \mathrm{OPEN}$ & 3.23 & $-3.56^{*}$ & 3.59 & -4.18 \\
\hline
\end{tabular}

\section{Table 3.}

\section{Results of F-Test}

The table reports the results for cointegration test based on Auto Regressive Distributed Lag (ARDL) procedure developed by Pesaran and Shin (1999) and Pesaran, Shin and Smith (2001). The null hypothesis of no cointegration is tested against an alternative of cointegration. $\mathrm{I}(0)$ and $\mathrm{I}(1)$ are the critical values for the lower and upper bounds, respectively, of the F statistic with constant and trend (Narayan, 2005). The sample period used is from 1995 to 2017. In the models, IIT, RDPCI, TB and FDI denote Intra-industry trade index, relative difference in per-capita income, trade balance, foreign direct investment, respectively. Similarly, MSD, HKE and Open denote market size differential, human capital differential and trade openness, respectively. In is the natural logarithm.

\begin{tabular}{|c|c|c|c|c|c|}
\hline \multirow[t]{2}{*}{ Models } & \multirow[t]{2}{*}{ Optimum lag (SBC) } & \multirow{2}{*}{$\begin{array}{l}\text { Optimum } \\
\text { lag (SBC) }\end{array}$} & \multirow{2}{*}{$\begin{array}{l}\text { Calculated } \\
\text { F-statistic }\end{array}$} & \multicolumn{2}{|c|}{$\begin{array}{c}\text { Critical values } \\
95 \% \text { level }\end{array}$} \\
\hline & & & & $\mathrm{I}(0)$ & $\mathrm{I}(1)$ \\
\hline Model 1 & $\begin{array}{l}\ln I I T_{t}=\gamma_{0}+\gamma_{1} \ln R D P C I_{t}+\gamma_{2} \ln T B_{t}+ \\
\gamma_{3} \ln F D I_{t}+\varepsilon_{t}\end{array}$ & 1 & 5.3 & 3.7 & 5.0 \\
\hline Model 2 & $\begin{array}{l}\ln I I T_{t}=\gamma_{0}+\gamma_{1} \ln M S D_{t}+\gamma_{2} \ln H K E_{t}+ \\
\gamma_{3} \ln F D I_{t}+\varepsilon_{t}\end{array}$ & 1 & 6.4 & 3.7 & 5.0 \\
\hline Model 3 & $\begin{array}{l}\ln I I T_{t}=\gamma_{0}+\gamma_{1} \ln R D P C I_{t}+\gamma_{2} \ln H K E_{t}+ \\
\gamma_{3} \ln F D I_{t}+\gamma_{3} \ln \mathrm{Open}_{t}+\varepsilon_{t}\end{array}$ & 1 & 6.9 & 3.3 & 4.7 \\
\hline
\end{tabular}

To test the long-run relationship between IIT and its determinants, we estimate three models. Table 3 displays the $F$-statistics calculated for the three models. ${ }^{10}$ It is evident that the $F$-values for all three models are higher than the critical values

${ }^{10}$ The main reason for not including all the variables in the equation is to maintain the degrees of freedom. 
of Narayan (2005) noted above, implying that the null of no cointegration can be rejected at the $5 \%$ level and there exists a long-run relationship, or cointegration, between the IIT index and its determinants. Having established the cointegration relationship, the next step is to estimate the long-run coefficients of the equation by using the ARDL specification. The estimated long-run coefficients of the ARDL models suggested by the Schwarz's Bayesian information criterion are shown in Table 4.

Table 4.

\section{Long-Run Coefficient Estimates by the ARDL Approach}

The table reports the long-run coefficients estimated by Auto Regressive Distributed Lag (ARDL) method to cointegration. Asterisks *** and ${ }^{* * *}$ denote statistical significance at the $1 \%, 5 \%$ and $10 \%$ levels, respectively and values in parenthesis indicate standard errors. The sample period used is from 1995 to 2017. In the models, IIT, RDPCI, $T B$ and FDI denote Intra-industry trade index, relative difference in per-capita income, trade balance, foreign direct investment, respectively. Similarly, MSD, HKE and Open denote market size differential, human capital differential and trade openness, respectively.

$\ln$ is the natural logarithm.

\begin{tabular}{lccc}
\hline \multirow{2}{*}{ Variables } & Model 1 & Model 2 & Model 3 \\
\cline { 2 - 4 } & ARDL(1,0,0,0) & ARDL(1,0,0,0) & ARDL(1,0,0,0,0) \\
\hline $\ln R D P C I$ & -1.154 & & -0.912 \\
& {$[0.2089]^{*}$} & & {$[0.304]^{* *}$} \\
$\ln T B$ & -0.488 & & \\
$\ln F D I$ & {$[0.1072]^{*}$} & 0.411 & 0.529 \\
& 0.206 & {$[0.090]^{*}$} & {$[0.202]^{*}$} \\
$\ln M S D$ & {$[0.058]^{*}$} & 2.908 & 1.352 \\
& & {$[2.55]$} & {$[1.404]$} \\
$\ln H K E$ & & -1.405 & \\
& & {$[0.473]^{* *}$} & \\
$\ln O P E N$ & & & 2.462 \\
& & & {$[0.971]^{* *}$} \\
Constant & 1.524 & -11.152 & 1.945 \\
& {$[0.507]^{*}$} & {$[4.453]^{* *}$} & {$[0.801]^{* *}$} \\
\hline
\end{tabular}

In Table 4, the long-run coefficients show that all the regressors in the bilateral trade equation exhibit their theoretically expected signs. Importantly, all the variables are statistically significant at the 5\% level in the long run. We now discuss this model in detail. The long-run elasticity of RDPCI is a measure of dissimilarities in income or demand structures between countries and it is statistically significant in the model. The high elasticity of RDPCI, -1.15 , indicates that a $1 \%$ increase in inequality in per capita income between India and Indonesia leads to $1.15 \%$ decrease in IIT. Hence, an increase in dissimilar income has a negative impact on IIT between these countries. This result also suggests that the lower values of IIT between India and Indonesia are partially due to the income gap between the two countries. Differing demand structures thus often create barriers to the extensive exchange of goods in the same categories and hence suppresses IIT. This result 
is similar to the findings of Linder (1961), Moreover, the negative relationship between RDPCI and IIT is well explained by theoretical models ( Falvey,1981; Falvey and Kierzkowski,1987; Helpman and Krugman,1985).

Similarly, the estimated coefficient of the Trade Balance (TB) is -0.48 and statistically significant, implying that the value of the IIT index decreases as trade imbalance increases. Therefore, improving the trade balance between countries can improve their IIT between them. Similarly, the variable FDI is statistically significant in all three models, with a coefficient ranging from 0.2 to 0.5 , implying that higher FDI inflows to India enhance the IIT between countries. The evidence of a positive impact of FDI on IIT shows that trade facilitation through FDI leads to greater product differentiation and more intense IIT.

\section{Table 5.}

\section{Error Correction Representation for the ARDL Model}

The table report the short-run coefficients estimated by Auto Regressive Distributed Lag (ARDL) approach to cointegration. In the models, IIT, RDPCI, TB and FDI denote Intra-industry trade index, relative difference in percapita income, trade balance, foreign direct investment, respectively. Similarly, MSD, HKE and Open denote market size differential, human capital differential and trade openness, respectively. $\ln$ is the natural logarithm. Where $D$ and $\mathrm{ecm}_{\mathrm{t}-1}$ denote first difference and error correction term, respectively. Similarly,

$\chi_{A C}^{2}$ and $\chi_{A R C H}^{2}$ are LM statistics for serial correlation and ARCH effects (at lag 1), respectively. Likewise, $\chi_{\text {NORMALITY }}^{2}$ is the LM statistic for normality in residual at

$\operatorname{lag} 2$, respectively. Finally, ${ }^{*}{ }^{* *}$ and ${ }^{* * *}$ denote statistical significance at the $1 \%, 5 \%$ and $10 \%$ levels, respectively. Figures in parenthesis are standard errors.

\begin{tabular}{lccc}
\hline \multirow{2}{*}{ Variables } & Model 1 & Model 2 & Model 3 \\
\cline { 2 - 4 } & ARDL(1,0,0,0) & ARDL(1,0,0,0) & ARDL $(\mathbf{1}, \mathbf{0 , 0 , 0 , 0 )}$ \\
\hline$\Delta \ln R D P C I$ & $1.112[0.204]^{*}$ & & $0.878[0.315]^{* *}$ \\
$\Delta \operatorname{lnTB}$ & $-0.226[0.089]^{* *}$ & & \\
$\Delta \operatorname{lnFDI}$ & $0.1988[0.085]^{* *}$ & $0.118[0.042]^{*}$ & $0.096[0.01]^{*}$ \\
$\Delta \operatorname{lnMSD}$ & & $0.213[0.734]$ & $-0.584[0.721]$ \\
$\Delta \operatorname{lnHKE}$ & & $-0.348[0.569]$ & \\
$\Delta \ln \mathrm{OPEN}$ & & & $1.102[0.66]$ \\
$E C M(-1)$ & $-0.962[0.149]^{*}$ & $-0.889[0.230]$ & $-0.964[0.22]^{*}$ \\
$R^{2}$ & 0.55 & 0.75 & 0.72 \\
$\chi_{A C}^{2}$ & $2.22[0.170]$ & $1.59[0.309]$ & $1.91[0.209]$ \\
$\chi_{A R C H}^{2}$ & $0.245[0.62]$ & $0.049[0.827]$ & $0.022[0.891]$ \\
$\chi_{\text {NORMALITY }}^{2}$ & $0.457[0.79]$ & $0.805[0.668]$ & $0.705[0.568]$ \\
CUSUM & Stable & Stable & Stable \\
CUSUMQ & Stable & Stable & Stable \\
\hline
\end{tabular}


Table 6.

\section{Long-Run Coefficient Estimates by the ARDL Approach}

The table reports the long-run coefficients estimated by Auto Regressive Distributed Lag (ARDL) method to cointegration. The sample period used is from 1995 to 2017. In the models, IIT, RDPCI, TB and FDI denote Intraindustry trade index, relative difference in per-capita income, trade balance, foreign direct investment, respectively. Similarly, MSD, HKE and Open denote market size differential, human capital differential and trade openness, respectively. Dum_1998 and Dum_2008 denotes the dummy variables that account for the shift in intercept. In denotes natural logarithm form. Finally, ${ }^{*}{ }^{* *}$ and ${ }^{* * *}$ denote statistical significance at the $1 \%, 5 \%$ and $10 \%$ levels, respectively, and values in parenthesis indicate standard errors.

\begin{tabular}{lccc}
\hline \multirow{2}{*}{ Variables } & Model 1 & Model 2 & Model 3 \\
\cline { 2 - 4 } & ARDL(1,1,0,0) & ARDL(1,1,0,0) & ARDL(1,1,0,0,0,0) \\
\hline $\ln R D P C I$ & -1.029 & & -0.854 \\
$\ln T B$ & {$[0.201]^{*}$} & & {$[0.412]^{* *}$} \\
$\operatorname{lnFDI}$ & -0.460 & & \\
& {$[0.129]^{*}$} & 0.396 & 0.510 \\
$\ln$ MSD & 0.202 & {$[0.093]^{*}$} & {$[0.131]^{*}$} \\
& {$[0.051]^{*}$} & 2.613 & 1.062 \\
$\ln H K E$ & & {$[2.43]$} & {$[1.510]$} \\
& & -1.316 & \\
$\operatorname{lnOPEN}$ & & {$[0.481]^{* *}$} & \\
& & & 2.258 \\
Dum_1998 & & & {$[0.962]^{* *}$} \\
& -0.523 & -0.502 & -0.543 \\
Dum_2008 & {$[1.322]$} & {$[1.132]$} & {$[1.322]$} \\
& -0.821 & -1.031 & -0.881 \\
Constant & {$[0.722]$} & {$[0.926]$} & {$[0.817]$} \\
& 1.313 & -10.164 & 1.727 \\
& {$[0.507]^{*}$} & {$[4.211]^{* *}$} & {$[0.907]^{* *}$} \\
\hline
\end{tabular}

Additionally, the estimated coefficient of the Market Size Differential (MSD) exhibits a positive sign, which is theoretically unexpected but statistically insignificant. This finding indicates that the disparity in market size between the two countries does not prevent the growth of IIT. The difference in Human Capital Endowment $(H K E)$, however, is statistically significant and exhibits a negative sign. The greater the disparity in human capital endowment, the lower the IIT, which suggests that reduction of the disparity in human capital endowments between countries through better skills training and education, for example, can improve IIT. Finally, the trade openness variable (Open) is positive and statistically significant, suggesting that India's trade liberalization has expanded IIT. This result is consistent with theoretical expectations.

The short-run dynamics of IIT through the error correction model is shown in Table 5. The signs of the short-run coefficients are consistent with theoretical predictions and are statistically significant in all three models. The error correction terms $\left(E C M_{t-1}\right)$ are significant at the $1 \%$ level in all four models and have the expected sign. The estimated coefficient of the error correction term ranges from -0.44 to -0.84 , indicating that more than $50 \%$ of the deviation from equilibrium 
is eliminated within one year. The diagnostics statistics reported in Table 6 do not show any serial correlation or autoregressive conditional heteroskedasticity effects in the residuals of the error correction model. Further, the models confirm normality in the residuals and a functional form test does not indicate any model misspecification. Moreover, the cumulative sum (CUSUM) and cumulative sum of squares (CUSUMQ) of the recursive residuals do not show evidence of any instability of the coefficients across sample periods. For a robustness check, first, we include slope dummy variables to capture the effects of the Indonesian financial crisis in 1998 and the global financial crisis in 2008 on IIT. Second, we use the Akaike information criterion as an alternative lag selection criterion. The estimated longrun coefficients are reported in Table 6 and show that the financial crises did not have a significant effect on bilateral IIT. Similarly, the overall empirical findings are consistent with the previous results reported Table 6.

\section{CONCLUSION}

India initiated the economic reforms during the early 1990s and its trade patterns have changed substantially. Focusing on India's growing trade with Indonesia, this paper analyzes the dynamic changes of India's bilateral IIT in commodity trade. IIT measures the simultaneous export and import of goods with the same product categories and hence an increase in IIT indicates progress in product variety, improved economies of scales, and reduced technology gaps with trading partners.

The study calculates a bilateral IIT index using commodity trade data at the two-digit BEC code level from 1995 to 2017. The estimates demonstrate the presence of IIT between the two countries, since the index is above 0.5 in most years. However, there is no remarkable increase in the intensity of IIT, implying meager reciprocal trade between the two countries. Our findings also show that IIT is mostly taking place in processed industrial supplies and capital goods and the trade pattern between the two countries has significantly changed in terms of composition, that is, shifting from labor-intensive to more capital-intensive products.

This paper also investigates the determinants of IIT and shows that the per capita income gap between the two countries has a significant role in determining IIT, indicating that dissimilar demand structures between countries can create barriers to extensively exchanging goods in the same categories. Similarly, the evidence from the analysis also notes the significant role of FDI in improving IIT, indicating that trade facilitation through FDI leads to greater product differentiation and more intense IIT. Hence efficiency-seeking FDI can play a crucial role in trade facilitation in India. The empirical findings of this paper also shed light on the role of human capital endowment in the two countries in determining IIT. This result suggests room for increasing intensity of IIT by reducing disparities in human capital endowment between countries by implementing various programs to enhance skills and education.

Finally, policies that facilitate more trade and fair trade by reducing barriers can undoubtedly improve economies of scale in trade between countries. Our empirical findings demonstrate that trade imbalance significantly reduces the 
level of India's IIT with Indonesia. India's large trade deficit with Indonesia could be a major cause of non-increasing trends in IIT. Therefore, policies are warranted to minimize the trade imbalance between the two countries, such as encouraging more exports to Indonesia, and to facilitate more trade by reducing trade barriers. There is ample scope for improving trade specialization through reciprocity in trading commodities between the two countries. This will reduce trade barriers and technology-led costs and allow supply chains to become both more regional and international. The absence of IIT in many commodity groups could be due to restrictions on them, such as tariffs and quotas. If IIT is to be encouraged between India and Indonesia, trade barriers need to be removed.

\section{REFERENCES}

Aggarwal, S., and Chakraborty, D. (2017). Determinants of India's Bilateral IntraIndustry Trade Over 2001-2015: Empirical Results. South Asia Economic Journal, 18, 296-313.

Andresen, M. A. (2003). Empirical Intra-Industry Trade: What We Know and What We Need to Know, Figure 3. IIT Index (Bilateral IIT between India and Indonesia)

Balassa, B. (1986). Intra-Industry Specialization a Cross-Country Analysis. European Economic Review, 30, 27-34.

Balassa, B., and Bauwens, L. (1987). Intra-Industry Specialization in a MultiCounty and Multi-Industry Framework. Economic Journal, 97, 923-939.

Baldwin, R.E. (1979). Determinants of Trade and Foreign Investment: Further Evidence. Review of Economics and Statistics, 61, 40-48.

Bergstrand, R.E. (1983). Measurement and Determinants of Intra-Industry International Trade. In Tharakan P.K.M. (Ed.) Intra-Industry Trade: Empirical And Methodological Aspect. Amsterdam, 201-262.

Brülhart, M. (1994). Marginal Intra-Industry Trade: Measurement and Relevance for the Pattern of Industrial Adjustment. Review of World Economics, 130, 600-613.

Burange, L. G., and Chaddha, S. J. (2008). Growth in India's Intra-Industry Trade. Working Paper UDE 24/2/2008, Mumbai: Department of Economics, University of Mumbai.

Caves, R.E. (1981). Intra-Industry Trade and Market Structure in the Industrial Countries. Oxford Economic Papers, 33, 203-223.

Chen, T. Y. (2000). Foreign Direct Investment and Intra-Industry Trade: The Case of the United States. Pacific Economic Papers, 302.

Clark, P.D., and Denise, L. (1999). Determinants of Intra-Industry Trade between Developing Countries and the United State. Journal of Economic Development, 24, 79-95.

Cortinhas, C. (2007). Intra-Industry Trade and Business Cycles in ASEAN. Applied Economics, 39, 893-902.

Davis, D.R. (1995). Intra-Industry Trade: A Heckscher-Ohlin-Ricardo Approach. Journal of International Economics, 39, 3-4.

Fainštein, G., and Netšunajev, A. (2011). Intra-Industry Trade and Development in the Baltic States. Emerging Markets Finance and Trade, 47, 95-110. 
Falvey, R. (1981). Commercial Policy and Intra-Industry Trade. Journal of International Economics, 11, 495-511.

Falvey, R., and Kierzkowski, H. (1986). Product Quality, Intra-Industry Trade and Imperfect Competition. In H. Kierzkowski (Ed.) Protection and Competition in International Trade. Oxford, Blackwell.

Greenaway, D., Hine, R.C., and Milner, C. (1994). Country-Specific Factors and Pattern of Horizontal and Vertical Intra-Industry Trade in the UK. Review of World Economics, 130, 77-100.

Grubel, H., and Lloyd, P. (1975). Intra-Industry Trade: The Theory and Measurement of International Trade in Differentiated Products. Macmillan, London.

Gullstrand, J. (2002). Does the Measurement of Intra-Industry Trade Matter? Review of World Economics,138, 317-339.

Haddad, M. (2007). Trade Integration in East Asia: The Role of China and Production Networks. Policy Research Working Paper; No. 4160. World Bank, Washington, DC.

Harrigan, J. (1994). Scale Economies and the Volume of Trade. The Review of Economics and Statistics, 76, 321-328.

Harrigan, J. (1996). Technology, Factor Supplies and International Specialization: Estimating the Neoclassical Model. NBER Working Papers, No. 5722, National Bureau of Economic Research, Cambridge.

Helpman, E., and Krugman, P. (1985). Market Structure and Foreign Trade: Increasing Returns, Imperfect Competition and the International Economy. MIT Press, Cambridge.

IMF. (2011). Changing Patterns of Global Trade, Prepared by the Strategy, Policy, and Review Department. International Monetary Fund, Washington.

Krugman, P.R. (1981). Intra-Industry Specialization and the Gains from trade. Journal of Political Economy, 89, 959-973.

Leamer, E. (1988). Measure of Openness. In Baldwin, R.E. (Ed.), Trade Policy Issues and Empirical Analysis. University of Chicago Press, Chicago.

Linder, S. (1961). An Essay on Trade and Transformation. John Wiley and Sons, New York.

Loertscher, R., and Wolter, F. (1980). Determinants of Intra-Industry Trade: Among Countries and Across Industries. Review of World Economics, 116, 289-293.

Markusen, J. (1983). Factor Movements and Commodity Trade AS Complements. Journal of International Economics, 13, 341-56.

Markusen, J., and Venables. A.J. (1998). Multinational Firms and the New Trade Theory. Journal of International Economics, 46, 183-203.

Markusen, J., and Vernables, A.J. (2000). The Theory of Endowment, Intra-Industry Trade and Multinational Trade. Journal of International Economics, 52, 209-234.

Maric, Z. (2011). Intra-Industry Trade and Economic Development (Case of Bosnia and Herzegovina). Journal of Economic and Politics of Transition, 27, 1-11

Menon, J. (1996). The Dynamics of Intra-Industry Trade in ASEAN. Asian Economic Journal, 10, 105-115.

Ministry of Commerce. (2016). Report on India-Indonesia Relations, Government of India. 
Narayan, P.K. (2005). The Saving and Investment Nexus for China: Evidence from Cointegration Tests. Applied Economics, 37, 1979-1990

OECD. (2018). International Trade and Balance of Payments Statistics. The Organization of Economic Co-Operation and Development. France.

Pesaran, M.H., and Shin, Y. (1999). Testing for the Existence of a Long-Run Relationship. DAE Working Paper 9622, Department of Applied Economics, University of Cambridge.

Pesaran, M.H., Shin.Y., and Smith, R.J. (2001). Bounds Testing Approaches to the Analysis of Long-Run Relationships. Journal of Applied Econometrics,16, 289326.

Sawyer, W. C., and Richard, S., and Kiril, T. (2010). Patterns and Determinants of Intra-Industry Trade in Asia. Journal of Asian Economics, 21, 485-493.

Sohn, C.H., and Zhang, Z. (2005). How Intra-Industry Trade is Related to Income Difference and Foreign Direct Investment in East Asia. Asian Economic Papers, 4, 143-156.

Thorpe, M., and Shang, Z. (2005). Study of the Measurement and Determinants of Intra-Industry Trade in East Asia. Asian Economic Journal, 19, 231-247.

Varma, P. (2015). An Analysis of Country Specific Determinants of Vertical and Horizontal Intra-Industry Trade in the Food Processing Sector of India. International Journal Trade and Global Markets, 8, 324-342.

Veeramani, C. (2002). Intra-Industry Trade of India: Trends and Country-Specific Factors. Review of World Economics, 138, 509-533.

Veeramani, C. (2007). Industry-Specific Determinants of Intra-Industry Trade in India. Indian Economic Review, 42, 211-219.

Wakasugi, R. (2007). Vertical Intra-Industry Trade and Economic Integration in East Asia. Asian Economic Papers, 6, 26-39.

Xing, Y. (2007). Foreign Direct Investment and China's Bilateral Intra-Industry Trade with Japan and the US. Journal of Asian Economics, 18, 685-700.

Zhang, Z., and Li,C. (2006). Country-Specific Factors and the Pattern of IntraIndustry Trade in China's Manufacturing. Journal of International Development, 18, 1137-1149. 


\section{Appendix}

\begin{tabular}{|c|c|c|}
\hline Variable Name & Variable Definition & Calculation and Source \\
\hline \multirow[t]{11}{*}{$R D P C I$} & $\begin{array}{l}\text { Relative Difference in Per Capita } \\
\text { Income }\end{array}$ & $\begin{array}{l}\text { Followed Balassa (1986) to construct the } \\
\text { index of relative inequality. }\end{array}$ \\
\hline & & {$[w \ln w+(1-w) \ln (1-w)]$} \\
\hline & & $\operatorname{INEQ}=1+\frac{\ln 2}{\ln }$ \\
\hline & & $G D P_{i}^{P C}$ \\
\hline & & Where $w=\frac{G D P_{i}^{P C}+G D P_{j}^{P C}}{l, j}$ are the \\
\hline & & respective countries, and PC stands for \\
\hline & & per capita. This index takes on values \\
\hline & & between 0 and 1 , with relative inequality \\
\hline & & increasing as the index increases. \\
\hline & & Source: World development indicators \\
\hline & & (World Bank) \\
\hline \multirow[t]{4}{*}{$T B$} & Trade Balance & Difference between India's aggregate \\
\hline & & exports and import to Indonesia. \\
\hline & & Source: United Nations' Comtrade \\
\hline & & database \\
\hline \multirow[t]{2}{*}{ FDI } & Foreign Direct Investment & Net FDI inflows to India \\
\hline & & Source: UNCTAD database \\
\hline \multirow[t]{4}{*}{ MSD } & The Market Size Differential & The absolute difference of total GNP \\
\hline & & between India and Indonesia \\
\hline & & Source: World development indicators \\
\hline & & (World Bank) \\
\hline \multirow[t]{6}{*}{ HKE } & Human Capital Endowment & The difference between two countries \\
\hline & & in the total number of students enrolled in \\
\hline & & tertiary education in a given academic year \\
\hline & & divided by country's population and \\
\hline & & multiplied by $1,00,000$ \\
\hline & & Source: UNESCO database \\
\hline \multirow[t]{3}{*}{ Open } & Trade openness & India's total trade (exports plus imports) \\
\hline & & to GDP. \\
\hline & & Source: Reserve Bank of India \\
\hline
\end{tabular}

